\title{
Development of Covalent Ligand-Receptor Pairs to Study the Binding Properties of Nonpeptidic Neurotensin Receptor 1 Antagonists
}

Ralf C. Kling, Manuel Plomer, Christopher Lang, Ashutosh Banerjee, Harald Hübner, Peter Gmeiner*

Department of Chemistry and Pharmacy, Emil Fischer Center, Friedrich Alexander University, Schuhstr. 19, 91052 Erlangen, Germany.

peter.gmeiner@fau.de

\section{SUPPORTING INFORMATION}

A) Supporting Information Figure S1 ..................................................... 2

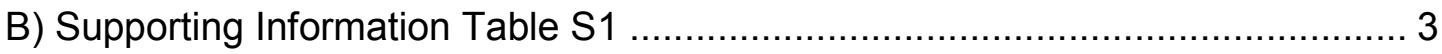

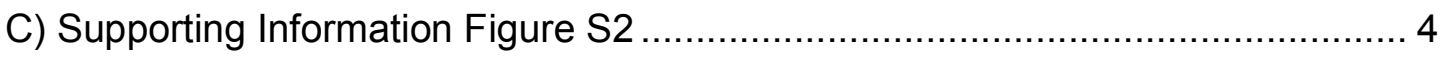

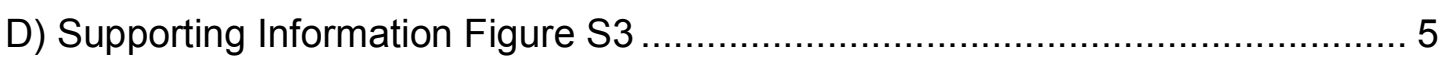

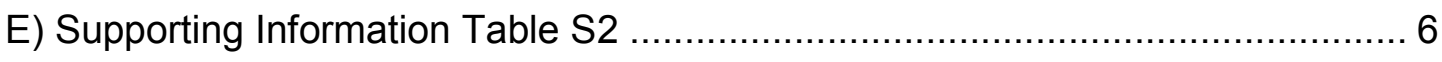

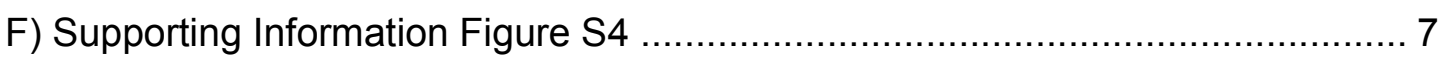

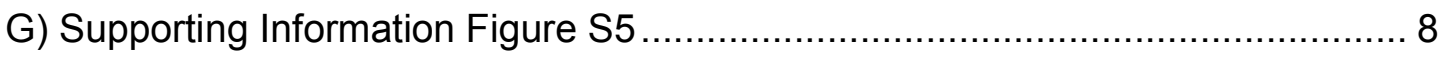

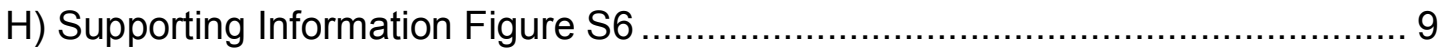

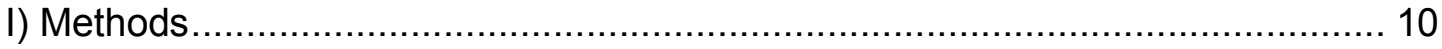

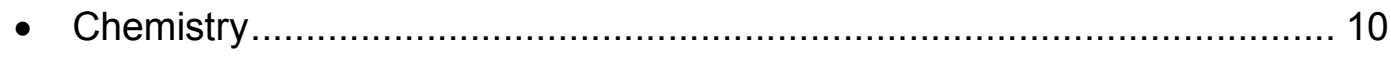

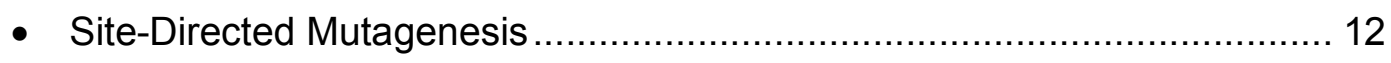

- Saturation-Binding Experiments and Receptor Binding Studies ............... 12

- Radioligand Depletion Assay ..................................................... 13

- Luciferase Reporter-Gene Assay ................................................. 13

- Computational Chemistry ......................................................... 14

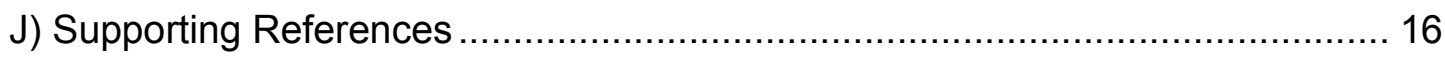




\section{A) Supporting Information Figure S1}

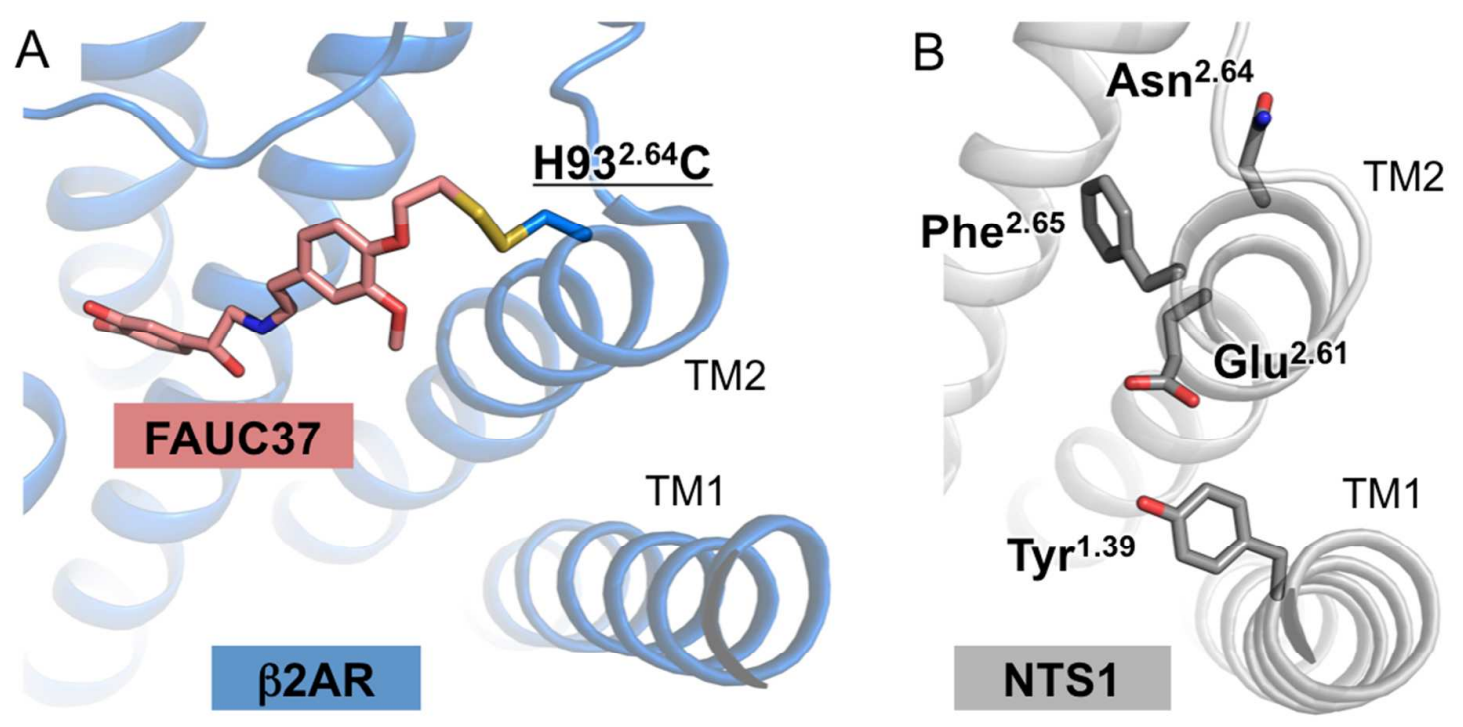

Figure S1. (A) Top view into the binding pocket of the $\beta 2 A R$ mutant $H 93^{2.64} \mathrm{C}$ (shown in blue), which is covalently tethered to the disulfide-functionalized ligand FAUC37 (shown as rose sticks) (PDB-ID: $4 \mathrm{QKX}{ }^{1}$ ). (B) Top view on helices TM1 and TM2 of the NTS1 receptor (shown in grey). The figure is derived from the crystal structure of rat NTS1 (PDB-ID: 4GRV²) and shows the location of residues $\mathrm{Tyr}^{1.39}, \mathrm{Glu}^{2.61}$ and Phe ${ }^{2.65}$, which have been mutated to cysteine within this study. Residue Asn $^{2.64}$ was not considered a suitable candidate as its side chain is not pointing into the binding pocket of NTS1. 


\section{B) Supporting Information Table S1}

\begin{tabular}{llcccc}
\hline & & \multicolumn{3}{c}{ NTS1 } \\
\cline { 3 - 5 } compound & & wildtype & Y1.39C & E2.61C & F2.65C \\
\hline & $\mathrm{B}_{\max }[\mathrm{fmol} / \mathrm{mg}]$ & $3500 \pm 750$ & $2200 \pm 540^{\mathrm{a}}$ & $180 \pm 64^{\mathrm{a}}$ & $2100 \pm 740$ \\
{$\left[^{3} \mathrm{H}\right] \mathrm{NT}(8-13)$} & $\mathrm{K}_{\mathrm{D}}[\mathrm{nM}]$ & $0.46 \pm 0.019$ & $1.3 \pm 0.5^{\mathrm{a}}$ & $4.6 \pm 1.4^{\mathrm{a}}$ & $0.90 \pm 0.15$ \\
\hline SR142948A & $\mathrm{K}_{\mathrm{i}}[\mathrm{nM}]$ & $0.59 \pm 0.18$ & $9.3 \pm 1.4$ & $0.97 \pm 0.27$ & $0.14 \pm 0.043$ \\
$\mathbf{1}$ & $\mathrm{K}_{\mathrm{i}}[\mathrm{nM}]$ & $4.0 \pm 1.4^{\mathrm{b}}$ & $28 \pm 5.5$ & $8.7 \pm 0.3^{\mathrm{a}}$ & $2.7 \pm 0.61$ \\
$\mathbf{2}$ & $\mathrm{K}_{\mathrm{i}}[\mathrm{nM}]$ & $5.5 \pm 0.07^{\mathrm{b}}$ & $37 \pm 2.5$ & $20 \pm 9.4^{\mathrm{a}}$ & $6.5 \pm 0.76$ \\
\hline
\end{tabular}

Table S1. Saturation binding data for NTS1 wildtype and the NTS1 mutant receptors $\mathrm{Y} 1.39 \mathrm{C}$, E2.61C and $\mathrm{F} 2.65 \mathrm{C}$ and receptor binding data for the compounds SR142948A, 1 and 2 employing NTS1 wildtype and the NTS1 mutant receptors $\mathrm{Y} 1.39 \mathrm{C}$, E2.61C and F2.65C. Unless stated otherwise, $K_{D}, B_{\max }$ and $K_{i}$ represent average values \pm SEM and are derived from 3-10 independent experiments, each performed as triplicates. ${ }^{a}$ Numbers are given as average values \pm SD derived from 2 independent experiments, each performed in triplicate. ${ }^{b} V a l u e s$ were obtained in the presence of $\left[{ }^{3} \mathrm{H}\right]$ neurotensin using homogenates of stably transfected NTS1 in $\mathrm{CHO}$ cells and represent average values \pm SD derived from 2 independent experiments, each performed as triplicates. 


\section{C) Supporting Information Figure S2}

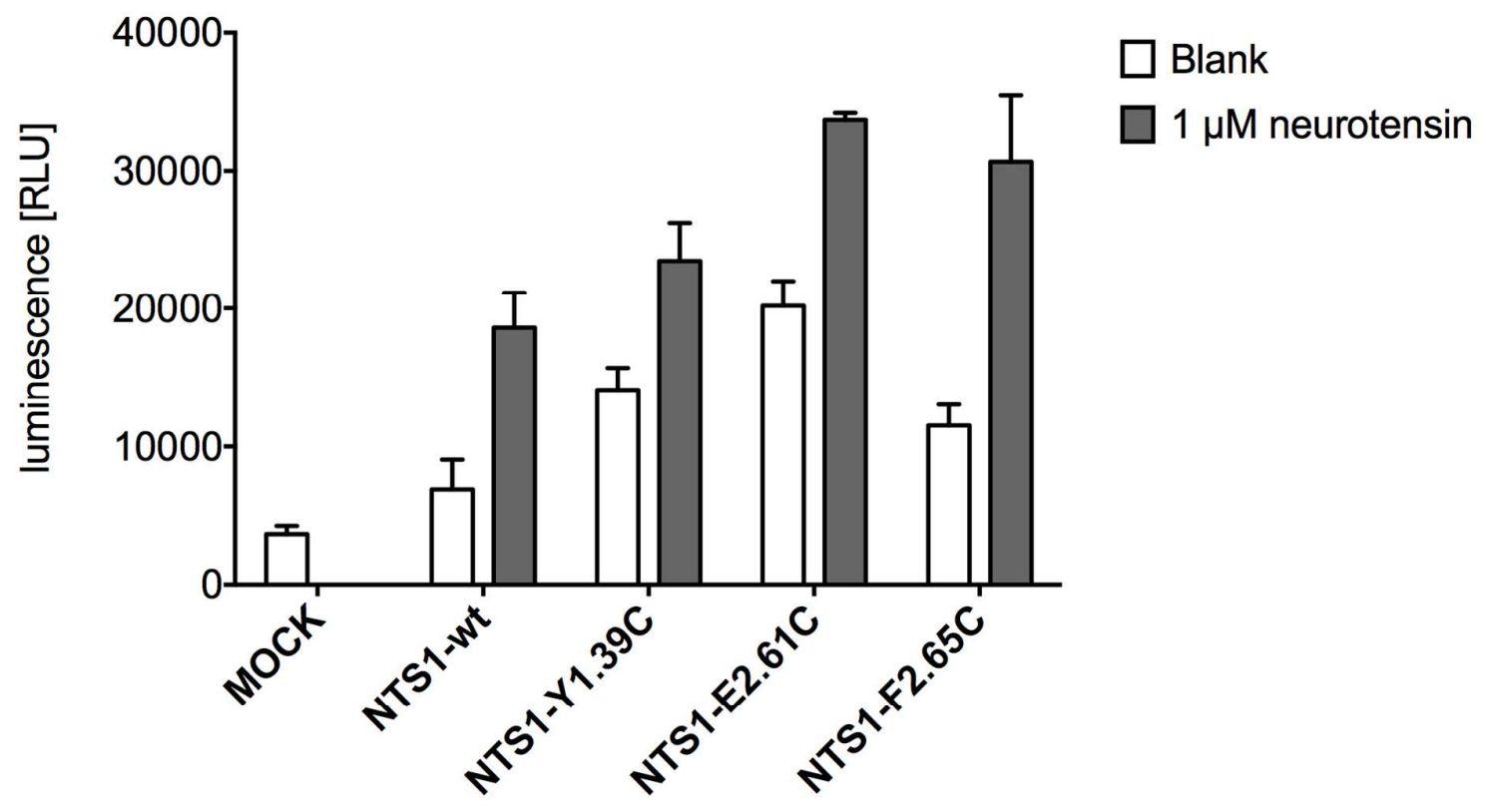

Figure S2. Basal and ligand-induced activity of the NTS1 mutants Y1.39C, E2.61C and F2.65C compared to wildtype. Data was determined by means of a MAPK-driven reporter gene assay. Average values \pm SEM are shown, obtained from 3 independent experiments (performed in parallel). 


\section{D) Supporting Information Figure S3}

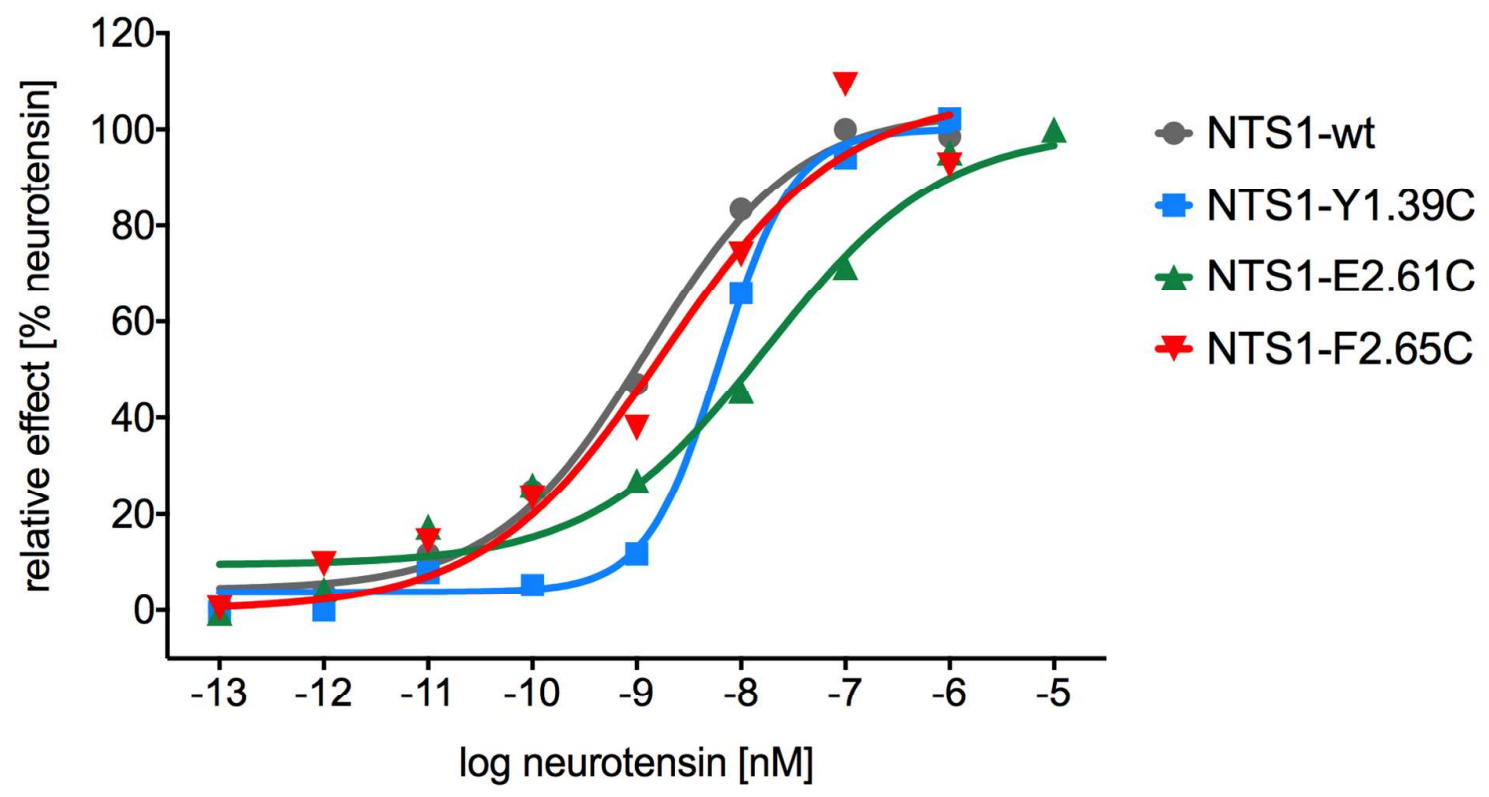

Figure S3. Dose-dependent activation of the NTS1 mutants Y1.39C, E2.61C and F2.65C compared to wildtype. Data was determined by means of a MAPK-driven reporter gene assay. Pooled curves \pm SEM are shown, obtained from 3-8 independent experiments, each performed as triplicates. 


\section{E) Supporting Information Table S2}

\begin{tabular}{lcccc}
\hline & \multicolumn{3}{c}{ NTS1 } \\
\cline { 2 - 5 } & wildtype & Y1.39C & E2.61C & F2.65C \\
\hline \multirow{2}{*}{ EC $_{50}[\mathrm{nM}]$} & 1.3 & 6.3 & 18 & 1.8 \\
& $(0.74-2.2)$ & $(3.8-10)$ & $(7.1-45)$ & $(0.55-6.1)$ \\
\hline
\end{tabular}

Table S2. Potency of neurotensin at the NTS1 mutants Y1.39C, E2.61C and F2.65C compared to wildtype. Data were determined by means of a MAPK-driven reporter gene assay. $\mathrm{EC}_{50}$ values (95\% confidence interval) from pooled curves are shown, obtained from 3-8 independent experiments, each performed as triplicates. 


\section{F) Supporting Information Figure S4}

A

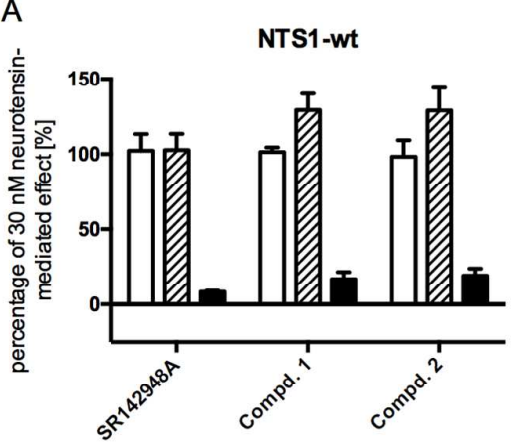

C

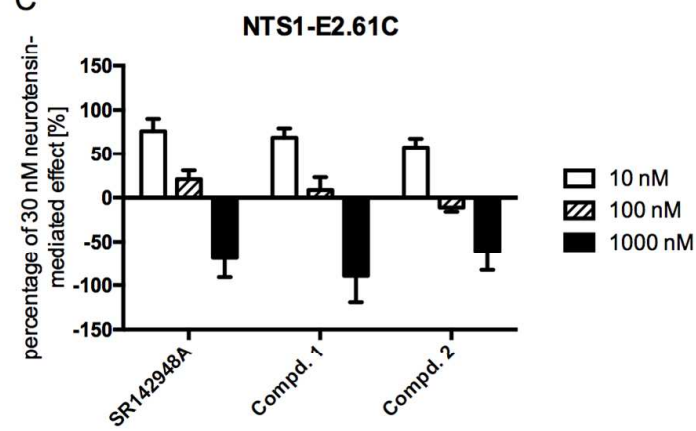

B
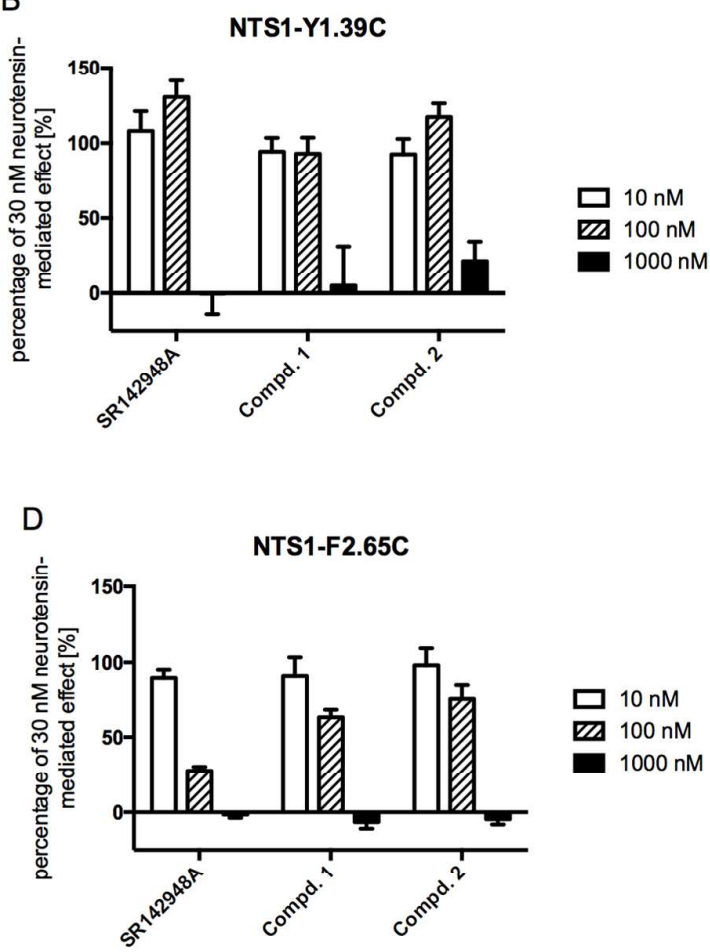

Figure S4. Inhibition of the neurotensin-mediated effect at NTS1 wildtype (A) and the receptor mutants Y1.39C (B), E2.61C (C) and F2.65C (D). Data was determined by means of the MAPK-driven reporter gene assay. Average values \pm SEM are shown, obtained from 3-4 independent experiments, each performed in parallel as triplicates. Absolute values of the negative data points have been normalized on the neurotensin-mediated effect. 


\section{G) Supporting Information Figure S5}

A
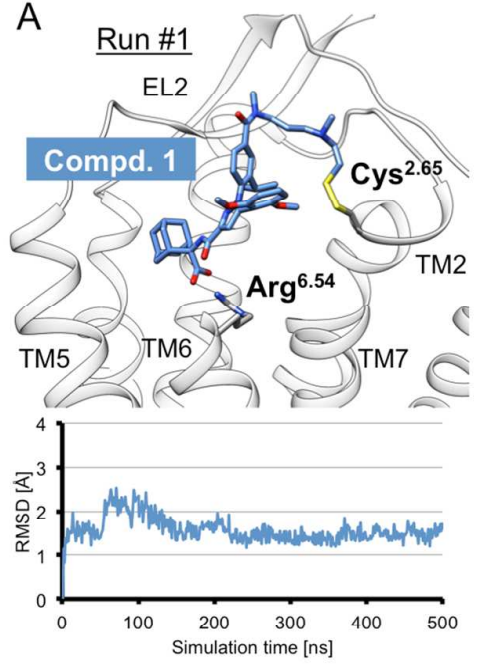

B
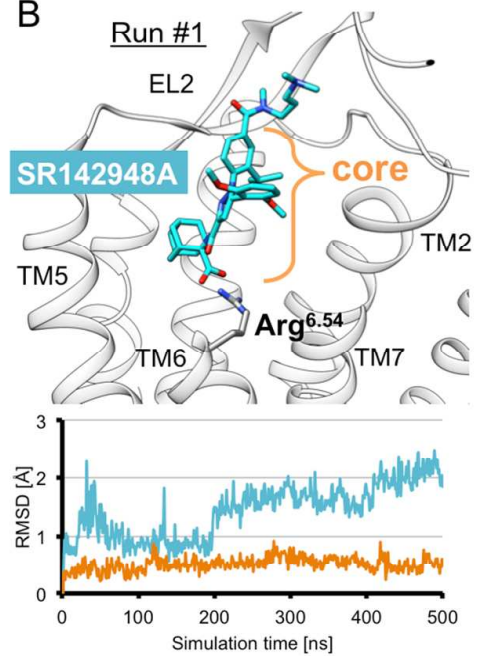
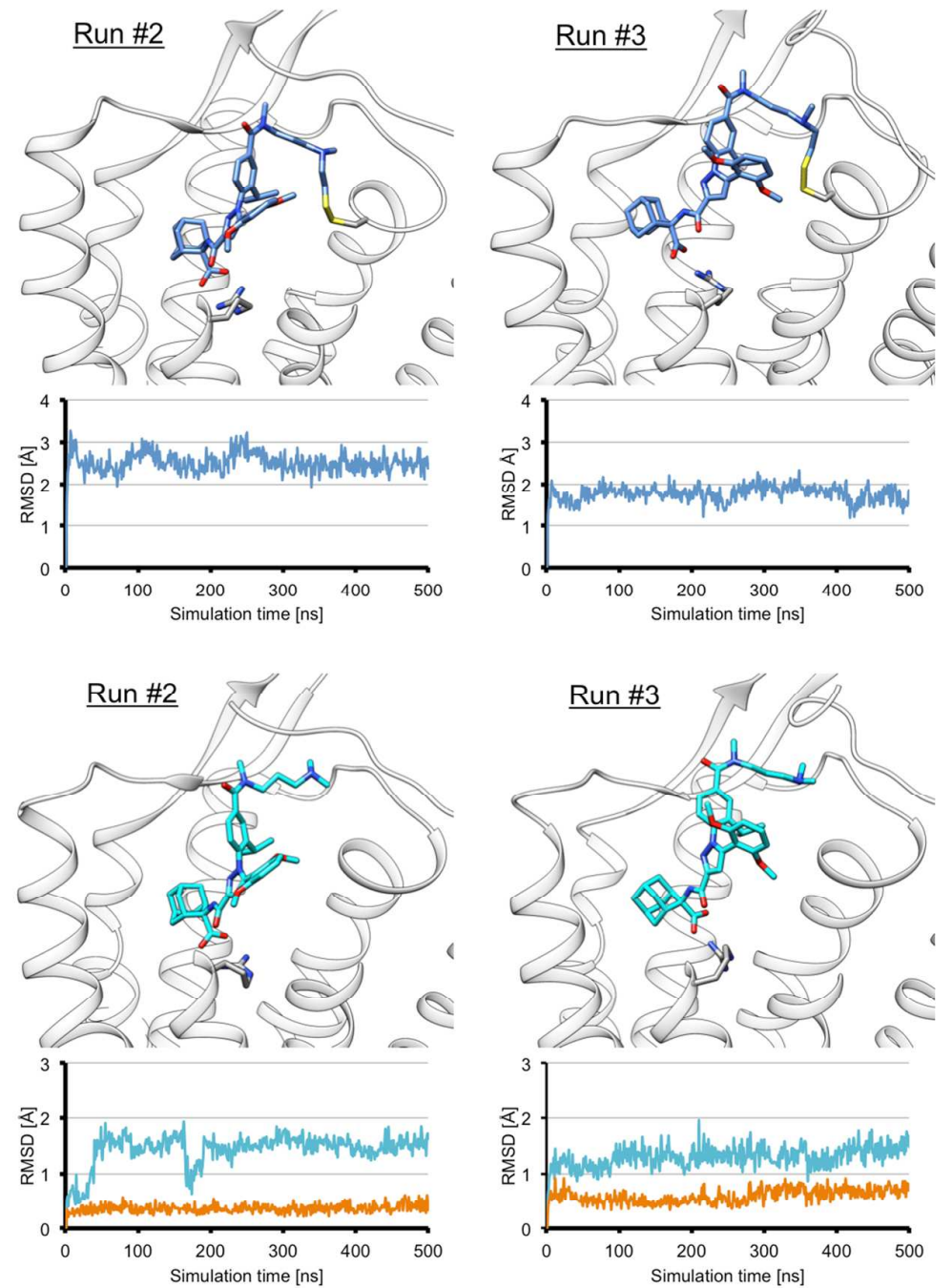

Figure S5. RMS-deviations of the individual simulation systems and representative snapshots from the final part of the individual simulation runs are shown. The ligands and the receptors are fitted on the $\mathrm{C} \alpha$-atoms of the receptors. (A) RMSD-values for compound 1 are depicted in blue. (B) RMSD-values for the core of SR142948A and its amine linker are shown in orange and cyan, respectively. 


\section{H) Supporting Information Figure S6}
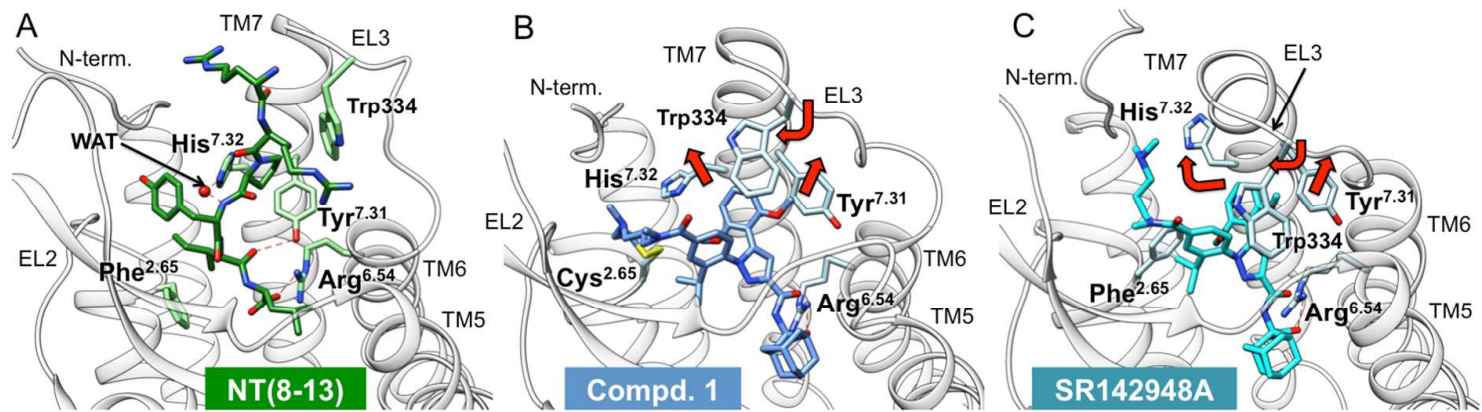

Figure S6. Comparison of the binding modes of NT(8-13) (green, A; PDB-ID: 4GRV ${ }^{2}$ ), compound 1 (blue, B) and SR142948A (cyan, C). The NTS1 receptor is shown in grey. Red arrows $(B, C)$ indicate antagonist-induced conformational changes of NTS1 residues Trp334 ${ }^{\mathrm{EL} 2}, \mathrm{Tyr}^{7.31}$ and His ${ }^{7.32}$ compared to the NT(8-13)NTS1 complex (A). 


\section{I) Methods}

Chemistry. All chemicals and solvents were obtained from commercial sources and used as received. Microwave reactions were conducted with a Biotage Initiator apparatus. For TLC, silica gel $60 \mathrm{~F} 254$ aluminum plates were used (UV, $\mathrm{KMnO}_{4}, \mathrm{I}_{2}$, and ninhydrin detection). Flash chromatography was performed using $60 \mu \mathrm{m}$ silica gel. Solvents were removed by rotary evaporation or lyophilization under reduced pressure. The final compounds were purified by preparative HPLC. IR spectroscopy was carried out on a FT/IR spectrometer as film on a $\mathrm{NaCl}$ plate or as solid using ATR-IR. NMR spectra were measured on a Bruker Avance 600 or a Bruker Avance 360 at $300 \mathrm{~K}$ unless otherwise noted. NMR chemical shifts are reported in ppm relative to TMS. HPLC-MS analyses were carried out on an analytical HPLC system with a VWL detector, coupled to a Bruker Esquire 2000-mass spectrometer with electron spray or atmospheric pressure chemical ionization (ESI or $\mathrm{APCl}$, respectively). ESI-TOF high mass accuracy and resolution experiments were performed on a Bruker maXis MS in the laboratories of the Chair of Bioinorganic Chemistry (Prof. Ivana Ivanović-Burmazović), Department of Chemistry and Pharmacy, FAU. Purities of the final products were assessed using the Agilent 1200 analytical HPLC equipped with a Zorbax Eclipse XDB-C8 column (4.6 × $150 \mathrm{~mm}, 5$ $\mu \mathrm{m}$, flow rate: $0.5 \mathrm{~mL} / \mathrm{min}$ ) and a diode array detector employing the gradient systems stated below.

2-(\{[5-(2,6-Dimethoxyphenyl)-1-(4-\{[\{3-[\{2-[(2-

hydroxyethyl)dithio]ethyl\}(methyl)amino]propyl\}(methyl)amino]carbonyl\}-2-

isopropylphenyl)-1H-pyrazol-3-yl]carbonyl\}amino)adamantan-2-carboxylic acid (1). In a Schlenk flask 4 (3.9 mg, $5.4 \mu \mathrm{mol})$ and dithiandiole $(1.6 \mathrm{mg}, 0.011 \mathrm{mmol})$ were dissolved in dry THF $(2 \mathrm{~mL})$ under nitrogen atmosphere. $\mathrm{NaBH}(\mathrm{OAc})_{3}(4.6 \mathrm{mg}, 0.022$ mmol) was added and the mixture was stirred at room temperature for $24 \mathrm{~h}$. Then dichlormethan $(1 \mathrm{~mL}), 2 \mathrm{~N} \mathrm{HCl}(0.13 \mathrm{~mL}), 2$-mercaptoethanol $(22.2 \mathrm{mg}, 20 \mu \mathrm{l}, 0.28$ $\mathrm{mmol}$ ) and 1,3-dibrom-5,5-dimethylhydantoin (46.3 $\mathrm{mg}, 0.162 \mathrm{mmol}$ ) were added. After stirring the reaction mixture for $1 \mathrm{~h}$ at room temperature, the solvent was evaporated under vacuum and the product was purified by preparative HPLC (Nucleodur C18 HTec $10 \mathrm{~mm} \times 250 \mathrm{~mm}, 5 \mu \mathrm{m}$; flow rate $4 \mathrm{~mL} / \mathrm{min}, \mathrm{MeCN} / \mathrm{H}_{2} \mathrm{O}(0.1$ $\left.\% \mathrm{HCO}_{2} \mathrm{H}\right)$ yielding $1.5 \mathrm{mg} 1(34 \%)$ as a white lyophilisate. ${ }^{1} \mathrm{H}-\mathrm{NMR}$ : $(600 \mathrm{MHz}$, DMSO d6) ; $\delta$ (ppm): 1.04 (s, 6 H), 1.48-1.84 (m, 10 H), 1.92-2.25 (m, 7 H), 2.50-2.58 
(m, $2 \mathrm{H})$, 2.59-2.97 (m, $8 \mathrm{H}), 3.07-3.62(\mathrm{~m}, 8 \mathrm{H}), 3.64(\mathrm{~s}, 6 \mathrm{H}), 6.61(\mathrm{~d}, J=8.4 \mathrm{~Hz}, 2$ H), $6.70(\mathrm{~s}, 1 \mathrm{H}), 7.09-7.20$ (m, $2 \mathrm{H}), 7.27-7.40(\mathrm{~m}, 3 \mathrm{H})$. APCI-MS: m/z 808.9 [M+H] $]^{+}$. HPLC purity $96.2 \%$ using ZORBAX ECLIPSE XDB-C8 (4.6 mm x $150 \mathrm{~mm}, 5 \mu \mathrm{m}$ ) flowrate $0.5 \mathrm{~mL} / \mathrm{min}, \mathrm{MeOH} / \mathrm{H}_{2} \mathrm{O}(0.1 \% \mathrm{HCOOH}), 10 \% 3 \mathrm{~min}, 10 \rightarrow 100 \%$ in 15 min, $100 \% 6 \mathrm{~min}, \mathrm{t}_{R}=18.4 \mathrm{~min}$. HRMS $\mathrm{C}_{42} \mathrm{H}_{57} \mathrm{~N}_{5} \mathrm{O}_{7} \mathrm{~S}_{2} \mathrm{H}, 808.37722$ (calculated), 808.37735 (found).

2-(\{[1-(4-\{[\{3-[[4-(1-\{2-[(2-Azidoethyl)dithio]ethyl\}-1H-1,2,3-triazol-4yl)butyl](methyl)amino]propyl\}(methyl)amino]carbonyl\}-2-isopropylphenyl)-5-(2,6dimethoxyphenyl)-1H-pyrazol-3-yl]carbonyl\}amino)adamantan-2-carboxylic acid (2). Compound 5 (3.8 mg, $5 \mu \mathrm{mol}$ ) and bis-(2-azidoethyl)disulfide $(4.8 \mathrm{mg}, 0.024 \mathrm{mmol})$ were dissolved in $\mathrm{H}_{2} \mathrm{O} / \mathrm{t}-\mathrm{BuOH}(1: 1,1 \mathrm{~mL})$. After addition of sodium ascorbate (4.8 $\mathrm{mg}, 0.024 \mathrm{mmol})$ and $\mathrm{CuSO}_{4}(0.3 \mathrm{mg}, 1.2 \mu \mathrm{mol})$ the mixture was stirred at room temperature. After $24 \mathrm{~h}$ additional amounts of sodium ascorbate $(19.2 \mathrm{mg}, 0.096$ $\mathrm{mmol})$ and $\mathrm{CuSO}_{4}(1.2 \mathrm{mg}(4.8 \mu \mathrm{mol})$ were added. After $24 \mathrm{~h}$ the mixture was purified without further workup by preparative HPLC (Nucleodur C18 HTec $10 \mathrm{~mm} \times 250 \mathrm{~mm}$, $5 \mu \mathrm{m}$; flow rate $4 \mathrm{~mL} / \mathrm{min}, \mathrm{MeCN} / \mathrm{H}_{2} \mathrm{O}\left(0.1 \% \mathrm{HCO}_{2} \mathrm{H}\right)$ yielding $2(0.52 \mathrm{mg}, 11 \%)$ as a white lyophilisat. APCI-MS: m/z 956.5 [M +H] $]^{+}$. HPLC purity $96.7 \%$ using ZORBAX ECLIPSE XDB-C8 (4.6 mm x $150 \mathrm{~mm}, 5 \mu \mathrm{m})$ flowrate $0.5 \mathrm{~mL} / \mathrm{min}, \mathrm{MeOH} / \mathrm{H}_{2} \mathrm{O}(0.1 \%$ $\mathrm{HCO}_{2} \mathrm{H}$ ), $10 \% 3 \mathrm{~min}, 10 \rightarrow 100 \%$ in $15 \mathrm{~min}, 100 \% 6 \mathrm{~min}, \mathrm{t}_{\mathrm{R}}=19.1 \mathrm{~min}$. HRMS: $\mathrm{C}_{48} \mathrm{H}_{65} \mathrm{~N}_{11} \mathrm{O}_{6} \mathrm{~S}_{2} \mathrm{H}, 956.4633$ (calculated) 956.4642 (found).

2-[(\{5-(2,6-Dimethoxyphenyl)-1-[2-isopropyl-4-(\{methyl[3-

(methylamino)propyl]amino\}carbonyl)phenyl]-1H-pyrazol-3-

y/3carbonyl)amino]adamantan-2-carboxylic acid (4). Compound 4 was synthesized and characterized according to a procedure reported previously. ${ }^{3}$

2-(\{[5-(2,6-Dimethoxyphenyl)-1-(4-\{[\{3-[hex-5-yn-1yl(methyl)amino]propyl\}(methyl)amino]carbonyl\}-2-isopropylphenyl)-1H-pyrazol-3yl]carbonyl\}amino)adamantan-2-carboxylic acid (5). Compound 5 was synthesized and characterized according to a procedure reported previously. ${ }^{4}$

Bis-(2-bromoethyl) disulfide. An aqueous solution of $\mathrm{HBr}(48 \%$ wt., $28 \mathrm{~mL})$ was added slowly under stirring to cooled $\left(0^{\circ} \mathrm{C}\right)$ conc. $\mathrm{H}_{2} \mathrm{SO}_{4}(20 \mathrm{~mL})$. Then bis-(2hydroxyethyl) disulfide (660 mg, $0.52 \mathrm{~mL}, 4.3 \mathrm{mmol}$ ) was added dropwise. The mixture was stirred at room temperature for $24 \mathrm{~h}$ followed by $3 \mathrm{~h}$ at $100^{\circ} \mathrm{C}$. After being cooled to room temperature dichloromethane $(20 \mathrm{~mL})$ was added. The reaction was quenched by the addition of satd. aqueous $\mathrm{NaHCO}_{3}$ and extracted with 
dichloromethane. The combined organic layers were dried over anhydrous $\mathrm{Na}_{2} \mathrm{SO}_{4}$ and concentrated in vacuo to obtain crude bis-(2-bromoethyl) disulfide (1.02 g, $85 \%)$ as pale yellow oil. ${ }^{1} \mathrm{H}-\mathrm{NMR}$ : $\left(600 \mathrm{MHz}, \mathrm{CDCl}_{3}\right) ; \delta(\mathrm{ppm}): 3.10(\mathrm{t}, J=8.0 \mathrm{~Hz}, 4 \mathrm{H})$, $3.62(\mathrm{t}, J=8.0 \mathrm{~Hz}, 4 \mathrm{H})$.

Bis-(2-azidoethyl) disulfide (6). Bis-(2-bromoethyl) disulfide (300 mg, 1.07 $\mathrm{mmol})$ and $\mathrm{NaN}_{3}(475 \mathrm{mg}, 7.3 \mathrm{mmol})$ were dissolved in DMF $(20 \mathrm{~mL})$ and heated at $80{ }^{\circ} \mathrm{C}$ for $7 \mathrm{~h}$. After cooling to room temperature the mixture was extracted with diethyl ether. The organic layer was washed with $\mathrm{NaCl}$ solution, dried over $\mathrm{MgSO}_{4}$ and concentrated in vacuo to obtain crude $6(180 \mathrm{mg}, 60 \%)$ as yellow oil. ${ }^{1} \mathrm{H}-\mathrm{NMR}$ : (600 MHz, $\left.\mathrm{CDCl}_{3}\right) ; \delta(\mathrm{ppm}): 2.88(\mathrm{t}, J=6.8 \mathrm{~Hz}, 4 \mathrm{H}), 3.60(\mathrm{t}, J=6.8 \mathrm{~Hz}, 4 \mathrm{H})$.

Site-Directed Mutagenesis. The human NTS1 receptor mutants $\mathrm{Y} 70^{1.39} \mathrm{C}, \mathrm{E} 123^{2.61} \mathrm{C}$ and $\mathrm{F} 127^{2.65} \mathrm{C}$ were obtained by site directed mutagenesis employing the polymerase chain reaction (PCR) as described. ${ }^{5}$ Fidelity of PCR amplification and introduction of mutations in the receptor cDNA was confirmed by sequencing at LCG Genomics (Berlin, Germany).

Saturation-Binding Experiments and Receptor Binding Studies. Binding data were determined according to protocols described previously. ${ }^{6}$ In detail, binding experiments with the human NTS1 wild type and mutant receptors were done using homogenates of membranes from HEK 293, which were transiently transfected with the pcDNA3.1(+) vector containing the desired gene by the commercially available TransIT-293 transfection reagent (Mirus Bio, Madison, USA).

For saturation experiments, the radioligand $\left[{ }^{3} \mathrm{H}\right] \mathrm{NT}(8-13)$ (specific activity $=136$ $\mathrm{Ci} / \mathrm{mmol}$, custom synthesis of [leucine- $\left.{ }^{3} \mathrm{H}\right] \mathrm{NT}(8-13)$ by GE Healthcare, Freiburg, Germany) was used at 9 different concentration in the range from $0.05 \mathrm{nM}$ to $5.0 \mathrm{nM}$. The assays were carried out in 96-well plates at protein concentrations of 10-350 $\mu \mathrm{g} / \mathrm{mL}$ in a final volume of $200 \mu \mathrm{L}$. Unspecific binding was determined in the presence of $10 \mu \mathrm{M} \mathrm{NT}(8-13)$ and the protein concentration was generally estimated by the method of Lowry using bovine serum albumin as standard. ${ }^{7}$

For competition binding experiments, the radioligand $\left[{ }^{3} \mathrm{H}\right] \mathrm{NT}(8-13)$ was used at a final concentration of $0.5 \mathrm{nM}$ and the test compounds at 8 different concentration in the range from $0.001 \mathrm{nM}$ to $10000 \mathrm{nM}$ using the same protocol as described above. 
Binding of compounds $\mathbf{1}$ and $\mathbf{2}$ at NTS1 wildtype was measured using homogenates of membranes from $\mathrm{CHO}$ cells stably expressing human NTS1 at a final concentration of $10 \mu \mathrm{g} / \mathrm{mL}$ and the radioligand $\left[{ }^{3} \mathrm{H}\right]$ neurotensin (specific activity 101 $\mathrm{Ci} / \mathrm{mmol} \square$; Perkin-Elmer, Rodgau, Germany) at a concentration of $0.50 \mathrm{nM}$. Specific binding of the radioligand was determined at $K_{D}$ values of $0.69 \mathrm{nM}$ and a $B_{\max }$ of $6200 \mathrm{fmol} / \mathrm{mg}$ protein. Nonspecific binding was determined in the presence of $10 \mu \mathrm{M}$ neurotensin.

For data analysis, the resulting competition curves of the receptor binding experiments were analyzed by nonlinear regression using the algorithms in PRISM 5.0 (GraphPad software, San Diego, CA). The data were initially fit using a sigmoid model to provide an $\mathrm{IC}_{50}$ value representing the concentration corresponding to $50 \%$ of maximal inhibition. $I_{50}$ values were transformed to $K_{i}$ values according to the equation of Cheng and Prusoff. ${ }^{8}$

Radioligand Depletion Assay. The radioligand depletion assay was performed in analogy to a protocol described earlier. ${ }^{1}$ Briefly, membranes from HEK 293 cells transiently expressing human NTS1 wild type or the human NTS1 receptor mutant $\mathrm{F} 127^{2.65} \mathrm{C}$ were preincubated in binding buffer $(50 \mathrm{mM}$ Tris, $1 \mathrm{mM}$ EDTA, $5 \mathrm{mM}$ $\mathrm{MgCl}_{2}, 100 \mu \mathrm{g} / \mathrm{mL}$ bacitracin, $5 \mu \mathrm{g} / \mathrm{mL}$ soybean trypsin inhibitor at $\mathrm{pH} 7.4$ ) at a protein concentration of $10 \mu \mathrm{g} / \mathrm{mL}$ and $50 \mu \mathrm{g} / \mathrm{mL}$, respectively, with the test compounds 1,2 and SR142948A (each at a final concentration of $10 \mathrm{nM}$ ) for $3 \mathrm{~h}$. Incubation was stopped by centrifugation and free ligand was washed out for three times (resuspension in buffer for $60 \mathrm{~min}$ and centrifugation). Membranes were then applied for radioligand binding experiments with $\left[{ }^{3} \mathrm{H}\right] \mathrm{NT}(8-13)$ or $\left[{ }^{3} \mathrm{H}\right] \mathrm{SR} 48692$ (specific activity $=81 \mathrm{Ci} / \mathrm{mmol}$, GE Healthcare, Freiburg, Germany) to determine specific binding at both NTS1 wild type and the mutant receptor $\mathrm{F} 127^{2.65} \mathrm{C}$ as described. ${ }^{6}$ Non-specific binding was determined in the presence of $10 \mu \mathrm{M} \mathrm{NT}(8-13)$.

Luciferase Reporter-Gene Assay. The luciferase reporter-gene assay was performed according to the manufacturer's instructions (PathDetect Elk1 TransReporting System, Stratagene, USA) following a protocol described previously. ${ }^{9}$ Briefly, HEK 293 cells were transfected with the TransIT-293 transfection reagent (Mirus Bio, Madison, USA). Twenty-four hours after transfection, cells were removed from the plate using versene and washed once to remove serum. Cells were 
resuspended in DMEM-F12 supplemented with 0.1\% FBS, $2 \mathrm{mM}$ L-glutamine, and $1 \%$ Pen-Strep and seeded into white half area 96-well plates (50000 cells/well). The test compounds were added at the indicated concentrations and incubated for $24 \mathrm{~h}$ at $37{ }^{\circ} \mathrm{C}$ and $5 \% \mathrm{CO}_{2}$. To quantify an increase in luciferase expression, $50 \mu \mathrm{L}$ of BrightGlo reagent (Promega, Mannheim, Germany) was added to each well. After 2 min of incubation at RT and constant agitation to achieve complete cell lysis, luminescence was measured with a multiplate reader (Viktor ${ }^{3} \mathrm{~V}$, Perkin-Elmer, Rodgau, Germany). Data analysis of the reporter-gene assay started when transforming the displayed luminescence values, which were given as relative luminescence units (RLU) into normalized data with basal effect set as $0 \%$ and the maximum effect of neurotensin as $100 \%$. The resulting curves were analyzed by nonlinear regression analysis to determine $\mathrm{EC}_{50}$ values representing the concentration corresponding to $50 \%$ of maximal efficacy.

Computational Chemistry. Using the crystal structure of the agonist-bound rat NTS1 as a template (PDB-ID: 4GRV²), we recently developed a homology model of human NTS1. ${ }^{10}$ Introduction of the F2.65C mutation was accomplished by means of PyMOL. ${ }^{11}$ The test compound 1 was docked manually into the $\mathrm{F} 2.65 \mathrm{C}$ mutant of our NTS1 model in a way to avoid steric clashes with residues of NTS1. Most importantly, the carboxylate moiety of $\mathbf{1}$ should form an ionic interaction with Arg322 6.54 of TM6, when the reactive disulfide group was positioned near to residue Cys $127^{2.65}$ of TM2. This initial conformation was relaxed during a two-step energy minimization procedure using AMBER $10 .{ }^{12}$ In the first step, we applied position restraints on all atoms of the receptor, while we adjusted the distances of (1) the central carbon atoms of the carboxylate of 1 and the guanidine group of $\operatorname{Arg} 322^{6.54}$ to $4.3 \AA$ and of (2) the sulfur atoms of 1 and Cys $127^{2.65}$, which are supposed to form the covalent ligand-receptor linkage, to $2.5 \AA$. In the second step, we kept the distance restraints of the first step, but allowed the side chains of the receptor to relax around the ligand. In both cases, we applied 500 steps of steepest descent minimization, followed by 4500 steps of conjugate gradient minimization. The minimization steps were carried out in a water box with periodic boundary conditions and a nonbonded cutoff of $10.0 \AA$. The all-atom force field ff $99 S B^{13}$ and the general AMBER force field $(G A F F)^{14}$ were used for the receptor and 1, respectively. Parameters for 1 were assigned using antechamber, and charges were calculated using Gaussian $09^{15}$ at 
the HF/6-31(d,p) level and the RESP procedure according to the literature. ${ }^{16}$ Next, the thus obtained ligand-receptor complex was used to form the covalent disulfide bond, in which 1 is irreversibly attached to the F2.65C mutant of the NTS1 model. The 1-F2.65C complex was submitted to unrestrained energy minimization (500 steps of steepest descent, 4500 steps of conjugate gradient), followed by a short MD simulation run of 5 ns (water box, periodic boundary conditions) to allow the tethered ligand to adapt to its binding site. The simulation steps were carried out as described previously. ${ }^{17}$ Parameters for the covalently attached ligand were assigned using a manually conducted RESP procedure on a Gaussian-optimized 1-cysteine hybrid, in which we adapted the charges of the 1 part while keeping the charges of the cysteine atoms at their values taken from the ff99SB force field. The force fields ff99SB and GAFF were used for the receptor and the covalently attached part of 1 . Missing parameters for the disulfide bond between the ligand and the receptor were added by hand according to the values for a disulfide bond between cysteine residues from within the ff99SB force field. The resulting complex was inserted into a lipidic bilayer of DOPC residues as described. ${ }^{17}$ The charges of the simulation system was neutralized by adding 9 chloride ions. This complex was submitted to a short simulation run of $10 \mathrm{~ns}$, with restraints of $1.0 \mathrm{kcal} \mathrm{mol}^{-1} \AA^{-2}$ applied on the main chain atoms of the proteins. Subsequently, we performed three individual MD simulation runs of 500ns each on the 1-F2.65C system with randomLy attributed initial velocities using the GROMACS simulation package ${ }^{18}$ as described. ${ }^{17}$ Based on the final snapshots of each 1-F2.65C simulation, we replaced 1 with SR142948A and restored the wildtype of NTS1 by mutating residue Cys $127^{2.65}$ back to phenylalanine. The resulting complexes were submitted to MD simulation runs of $500 \mathrm{~ns}$ as described above. Parameters for SR142948A were assigned using antechamber, and charges were calculated using Gaussian09 at the HF/6-31(d,p) level and the RESP procedure according to the literature. During the MD simulations, GAFF was used for SR142948A. 


\section{J) Supporting References}

1. Weichert, D., Kruse, A. C., Manglik, A., Hiller, C., Zhang, C., Hubner, H., Kobilka, B. K., and Gmeiner, P. (2014) Covalent agonists for studying G proteincoupled receptor activation, Proc Natl Acad Sci U S A 111, 10744-10748.

2. White, J. F., Noinaj, N., Shibata, Y., Love, J., Kloss, B., Xu, F., GvozdenovicJeremic, J., Shah, P., Shiloach, J., Tate, C. G., and Grisshammer, R. (2012) Structure of the agonist-bound neurotensin receptor, Nature 490, 508-513.

3. Lang, C., and Gmeiner, P. (2013) Efficient Synthesis of Heterocyclic Neurotensin Receptor Ligands by Microwave-Assisted Aminocarbonylation, Synthesis 45, 2474-2480.

4. Lang, C., Maschauer, S., Hubner, H., Gmeiner, P., and Prante, O. (2013) Synthesis and evaluation of a (18)F-labeled diarylpyrazole glycoconjugate for the imaging of NTS1-positive tumors, J Med Chem 56, 9361-9365.

5. Ehrlich, K., Gotz, A., Bollinger, S., Tschammer, N., Bettinetti, L., Harterich, S., Hubner, H., Lanig, H., and Gmeiner, P. (2009) Dopamine D2, D3, and D4 selective phenylpiperazines as molecular probes to explore the origins of subtype specific receptor binding, J Med Chem 52, 4923-4935.

6. Hubner, H., Haubmann, C., Utz, W., and Gmeiner, P. (2000) Conjugated enynes as nonaromatic catechol bioisosteres: synthesis, binding experiments, and computational studies of novel dopamine receptor agonists recognizing preferentially the $\mathrm{D}(3)$ subtype, J Med Chem 43, 756-762.

7. Lowry, O. H., Rosebrough, N. J., Farr, A. L., and Randall, R. J. (1951) Protein measurement with the Folin phenol reagent, J Biol Chem 193, 265-275.

8. Cheng, Y., and Prusoff, W. H. (1973) Relationship between the inhibition constant (K1) and the concentration of inhibitor which causes 50 per cent inhibition (I50) of an enzymatic reaction, Biochem Pharmacol 22, 3099-3108.

9. Einsiedel, J., Held, C., Hervet, M., Plomer, M., Tschammer, N., Hubner, H., and Gmeiner, P. (2011) Discovery of highly potent and neurotensin receptor 2 selective neurotensin mimetics, J Med Chem 54, 2915-2923.

10. Schaab, C., Kling, R. C., Einsiedel, J., Hübner, H., Clark, T., Seebach, D., and Gmeiner, P. (2014) Structure-Based Evolution of Subtype-Selective Neurotensin Receptor Ligands, ChemistryOpen 3, 206-218.

11. Schrodinger, L. (2010) The PyMOL Molecular Graphics System, Version 1.3r1.

12. Case, D. A., Darden, T. A., Cheatham, I., T. E., Simmerling, C. L., Wang, J., Duke, R. E., Luo, R., Crowley, M., Walker, R. C., Zhang, W., Merz, K. M., Wang, B., Hayik, S., Roitberg, A., Seabra, G., Kolossváry, I., Wong, K. F., Paesani, F., Vanicek, J., Wu, X., Brozell, S. R., Steinbrecher, T., Gohlke, H., Yang, L., Tan, C., Mongan, J., Hornak, V., Cui, G., Mathews, D. H., Seetin, M. G., Sagui, C., Babin, V., and Kollman, P. A. (2008) AMBER 10.

13. Hornak, V., Abel, R., Okur, A., Strockbine, B., Roitberg, A., and Simmerling, C. (2006) Comparison of multiple Amber force fields and development of improved protein backbone parameters, Proteins 65, 712-725.

14. Wang, J., Wolf, R. M., Caldwell, J. W., Kollman, P. A., and Case, D. A. (2004) Development and testing of a general amber force field, $J$ Comput Chem 25, 1157-1174.

15. Frisch, M. J., Trucks, G. W., Schlegel, H. B., Scuseria, G. E., Robb, M. A., Cheeseman, J. R., Scalmani, G., Barone, V., Mennucci, B., Petersson, G. A., Nakatsuji, H., Caricato, M., Li, X., Hratchian, H. P., Izmaylov, A. F., Bloino, J., Zheng, G., Sonnenberg, J. L., Hada, M., Ehara, M., Toyota, K., Fukuda, R., 
Hasegawa, J., Ishida, M., Nakajima, T., Honda, Y., Kitao, O., Nakai, H., Vreven, T., Montgomery, J. A., Peralta, J. E., Ogliaro, F., Bearpark, M., Heyd, J. J., Brothers, E., Kudin, K. N., Staroverov, V. N., Kobayashi, R., Normand, J., Raghavachari, K., Rendell, A., Burant, J. C., lyengar, S. S., Tomasi, J., Cossi, M., Rega, N., Millam, J. M., Klene, M., Knox, J. E., Cross, J. B., Bakken, V., Adamo, C., Jaramillo, J., Gomperts, R., Stratmann, R. E., Yazyev, O., Austin, A. J., Cammi, R., Pomelli, C., Ochterski, J. W., Martin, R. L., Morokuma, K., Zakrzewski, V. G., Voth, G. A., Salvador, P., Dannenberg, J. J., Dapprich, S., Daniels, A. D., Farkas, Foresman, J. B., Ortiz, J. V., Cioslowski, J., and Fox, D. J. (2009) Gaussian 09, Revision B.01, Wallingford CT.

16. Bayly, C. I., Cieplak, P., Cornell, W., and Kollman, P. A. (1993) A well-behaved electrostatic potential based method using charge restraints for deriving atomic charges: the RESP model, The Journal of Physical Chemistry 97, 10269-10280.

17. Möller, D., Kling, R. C., Skultety, M., Leuner, K., Hubner, H., and Gmeiner, P. (2014) Functionally Selective Dopamine D2, D3 Receptor Partial Agonists, J Med Chem 57, 4861-4875.

18. Hess, B., Kutzner, C., van der Spoel, D., and Lindahl, E. (2008) GROMACS 4: Algorithms for Highly Efficient, Load-Balanced, and Scalable Molecular Simulation, Journal of Chemical Theory and Computation 4, 435-447. 